\title{
Phylogenetic Analysis of Mycoplasma Strain ISM1499 and Its Assignment to the Acholeplasma oculi Strain Cluster
}

\author{
SERGEY ARTIUSHIN, ${ }^{1}$ MEL DUVALL, ${ }^{2}$ AND F. CHRIS MINION ${ }^{1 *}$ \\ Veterinary Medical Research Institute, Iowa State University, Ames, Iowa 50011, ${ }^{1}$ and Department of Biology \\ and Microbiology, South Dakota State University, Brookings, South Dakota 57077-05952
}

\begin{abstract}
A mycoplasma strain designated ISM1499 was used to develop a mycoplasma genetic system (G. G. Mahairas and F. C. Minion, J. Bacteriol. 171:1775-1780, 1989; G. G. Mahairas, C. Jian, and F. C. Minion, Gene 93:61-65, 1990), but phenotypic inconsistencies led to the conclusion that this organism had been classified incorrectly as a member of the species Mycoplasma pulmonis. Studies were initiated to determine the proper taxonomic position of ISM1499, and on the basis of the results of our genetic analysis, this strain was assigned to the Acholeplasma oculi strain cluster. The base composition of strain ISM1499 was identical to the base composition of $A$. oculi 19L, but not to the base composition of Acholeplasma laidlawii PG8 (28.3 and $30.7 \mathrm{~mol} \%$ G+C, respectively). The taxonomic position of ISM1499 was examined by performing a parsimony analysis with $16 \mathrm{~S}$ ribosomal DNA sequence data, and the results were compared with previous phylogenetic reconstructions. Our results indicated that ISM1499 is more closely related phylogenetically to $A$. oculi $19 \mathrm{~L}$ than to $A$. laidlawii PG8 and JA1. Heterogeneity in the 16S ribosomal DNA sequences of $A$. oculi 19L and ISM1499 and in the 16S ribosomal DNA sequences of $A$. laidlawii PG8 and JA1 may indicate that unusual dissimilarities occur in the $16 \mathrm{~S}$ ribosomal DNA sequences of members of the genus Acholeplasma.
\end{abstract}

Mycoplasma strain ISM1499 was originally isolated from a Mycoplasma pulmonis culture as a high-frequency transforming isolate. This organism was used to study mycoplasma transformation and to establish a mycoplasmal cloning system (9-12). On the basis of the results of these studies and Western blot (immunoblot) analyses performed with antisera raised in rabbits against a $M$. pulmonis stock strain by Minion and coworkers, strain ISM1499 was assumed to be a M. pulmonis strain, possibly a membrane or restriction mutant with a mutation which conveyed upon it the high-frequency transforming phenotype.

Dybvig and coworkers first noticed differences between ISM1499 and other $M$. pulmonis strains when they examined $\operatorname{rec} A$ homology and phage typing data $(4,5)$. A serological examination by J. G. Tully (Mycoplasmology Section, Laboratory of Medical Microbiology, National Institute of Allergy and Infectious Diseases confirmed that ISM1499 is an Acholeplasma strain rather than an $M$. pulmonis strain; this resulted in author's corrections being placed in both the Journal of Bacteriology and Plasmid $(11,12)$. The serological typing results indicated that ISM1499 is antigenically related to Acholeplasma oculi and Acholeplasma laidlawii; the strongest reactivity was obtained with an anti- $A$. oculi $19 \mathrm{~L}$ antiserum.

The class Mollicutes comprises a unique group of eubacteria that lack cell walls (17). In a newly proposed classification scheme Tully et al. (24) divided these organisms into eight genera on the basis of the phylogenetic data of Weisburg et al. (26) and various other characteristics, including a sterol growth requirement (the genera Mycoplasma, Ureaplasma, Entomoplasma, Spiroplasma, and Anaeroplasma), a positive urease reaction (the genus Ureaplasma), helicity (the genus Spiroplasma), oxygen sensitivity (the genera Anaeroplasma and Asteroleplasma), and lack of a sterol growth requirement (the

\footnotetext{
* Corresponding author. Mailing address: Veterinary Medical Research Institute, Iowa State University, 1802 Elwood Drive, Ames, IA 50011. Phone: (515) 294-6347. Fax: (515) 294-1401. Electronic mail address: fcminion@iastate.edu.
}

genera Mesoplasma, Acholeplasma, and Asteroplasma). There are other distinguishing features, but typically, the mycoplasmas and ureaplasmas are considered to be human and animal pathogens; spiroplasmas, entomoplasmas, and mesoplasmas are insect and plant pathogens or commensal organisms, and the acholeplasmas, anaeroplasmas, and asteroplasmas are generally considered commensal organisms.

The genus Acholeplasma currently includes nine recognized species that have been differentiated by a limited number of biochemical properties and by serological techniques. Serological procedures have proven to be very useful for separating species in the genus Mycoplasma, but the use of such procedures with Acholeplasma species has been problematic. Acholeplasmas are ubiquitous, and low anti-acholeplasma antibody levels in preimmune rabbit sera are often found (23). In addition, acholeplasmas adsorb serum proteins to their membranes, resulting in the production of antibodies to these proteins and potential serological cross-reactions between species. Both of these phenomena undoubtedly led to confusion in laboratories concerning the correct genus and species of isolate ISM1499. Also, growth-inhibiting antibodies produced in rabbits often have low potency (23). Several investigators have also examined acholeplasmas by performing nucleic acid hybridization experiments $(1,18)$, and their results have indicated that acholeplasma species exhibit little interspecific homology at the whole-genome level and that species designations may represent clusters within the genus Acholeplasma that exhibit substantial discontinuities.

Because of the importance of the genetic studies performed with strain ISM1499 to the field of mycoplasma genetics, it was important to establish the identity of this strain conclusively. We performed studies to analyze phylogenetically the $16 \mathrm{~S}$ rRNA sequence of ISM1499. It was necessary to sequence the 16S rRNA genes of $A$. oculi 19L (= ATCC 27350) and $A$. laidlawii PG8 (= ATCC 23206) as well. On the basis of the results of this analysis, the results of an examination of the guanine-plus-cytosine $(\mathrm{G}+\mathrm{C})$ contents of these species, and the results of serological typing experiments, strain ISM1499 was assigned to the $A$. oculi strain cluster. 
TABLE 1. Bacterial strains used in this study

\begin{tabular}{|c|c|c|}
\hline Species & Strain & $\begin{array}{c}\text { GenBank } \\
\text { accession } \\
\text { no. }\end{array}$ \\
\hline Acholeplasma laidlawii & PG8 (= ATCC 23206) & \\
\hline Acholeplasma oculi & $\begin{array}{l}\text { 19L (= ATCC 27350) } \\
\text { ISM1499 }\end{array}$ & $\begin{array}{l}\mathrm{U}_{14904^{a}} \\
\mathrm{U} 14906^{a}\end{array}$ \\
\hline Acholeplasma modicum & PG49 (= ATCC 29102) & M23933 \\
\hline Anae & $6-1(=\mathrm{ATCC}$ & 125050 \\
\hline Anaeroplasma bactoclasticum & $\mathrm{JR}(=\mathrm{ATC}$ & M25049 \\
\hline Anaeroplasma varium & A-2 $(=$ ATCC 43167$)$ & M23934 \\
\hline Clostridium ramosum & 113-I (= ATCC 25582) & M23731 \\
\hline Mycoplasma flocculare & Ms42 (= ATCC 27399) & X62699 \\
\hline lasma hominis & $=$ ATCC 23114) & M24473 \\
\hline moniae & ATC & Y00149 \\
\hline Mycoplasma iowae & $695(=$ ATCC 33552) & M24293 \\
\hline Mycoplasma mycoides & UM30847 & M23943 \\
\hline Mycoplasma pneumoniae & Eaton $(=A$ & M29061 \\
\hline Spiroplasma citri & (27556) & M23942 \\
\hline Ureaplasma ureal & $960(=$ NCTC 10177$)$ & M23935 \\
\hline
\end{tabular}

${ }^{a}$ Determined in this study.

\section{MATERIALS AND METHODS}

Bacterial strains. Table 1 shows the strains used in this study. In some instances, the 16S rRNA sequences were obtained directly from the GenBank database. Standard PPLO broth medium supplemented with $10 \%$ agamma horse serum, $2.5 \%$ fresh yeast extract, and $0.5 \%$ glucose (12) was used to grow all mycoplasma strains.

Nucleic acid preparation. Genomic DNAs from $A$. laidlawii PG8 (= ATCC 23206), A. oculi 19L (= ATCC 27350), and ISM1499 were prepared as follows. Cells from a $10-\mathrm{ml}$ culture were harvested by centrifugation at $20,000 \times g$ for 15 min at $4^{\circ} \mathrm{C}$, washed once with Tris-saline $(0.1 \mathrm{M}$ Tris, $0.14 \mathrm{M} \mathrm{NaCl}[\mathrm{pH} 7.4])$, and resuspended in $100 \mu \mathrm{l}$ of Tris-EDTA buffer. A $100-\mu 1$ portion of a solution containing $1 \%$ sodium dodecyl sulfate and $400 \mu \mathrm{g}$ of proteinase $\mathrm{K}$ per ml was added, and the mixture was incubated for $1 \mathrm{~h}$ at $37^{\circ} \mathrm{C}$. The DNA-containing solution was then extracted twice with phenol-chloroform (1:1) and once with chloroform and then precipitated with 2 volumes of ethanol. The DNA was solubilized in Tris-EDTA buffer. Aliquots were electrophoresed in a $0.7 \%$ agarose gel and stained with ethidium bromide to verify DNA integrity. DNA concentrations were determined by fluorescence with a model TKO 100 minifluorometer (Bio-Rad Laboratories, Richmond, Calif.).

PCR amplification and $16 S$ ribosomal DNA (rDNA) purification. A 0.2 - to $0.5-\mu \mathrm{g}$ portion of DNA was amplified in a $100-\mu \mathrm{l}$ reaction mixture. Each reaction mixture contained $50 \mathrm{mM} \mathrm{KCl}, 10 \mathrm{mM}$ Tris- $\mathrm{HCl}$ (pH 9.0), $0.1 \%$ Triton X-100, 2 $\mathrm{mM} \mathrm{MgCl} 2$, primers (each at a concentration of $0.6 \mu \mathrm{M}$ ), each deoxyribonucleoside triphosphate at a concentration of $200 \mu \mathrm{M}$, and $1 \mathrm{U}$ of Taq DNA polymerase (Gibco BRL, Gaithersburg, Md.). The primers used were primers fD1 (ccgaatt cgtcgacaacAGAGTTTGATCCTGGCTCAG) and RP1 (cccgggatccaagcttACGG TTACCTTGTTACGACTT) of Weisburg et al. (25), which are complementary to the $5^{\prime}$ and $3^{\prime}$ ends, respectively, of the 16S rRNAs of most eubacteria. Oligonucleotides were synthesized by standard methods with an automated DNA synthesizer (Applied Biosystems, Foster City, Calif.). PCR were performed in an Ericomp twin-block temperature cycler (Ericomp, Inc., San Diego, Calif.). The thermal profile involved 30 cycles of denaturation at $93^{\circ} \mathrm{C}$ for $1 \mathrm{~min}$, annealing at $42^{\circ} \mathrm{C}$ for $1 \mathrm{~min}$, and extension at $72^{\circ} \mathrm{C}$ for $3 \mathrm{~min}$. In the final cycle, primers were extended for $6 \mathrm{~min}$. Aliquots of amplified samples were analyzed by electrophoresis on a $1.5 \%$ agarose gel and stained with ethidium bromide. The resulting PCR-amplified 1.5 -kb fragment was purified by agarose gel electrophoresis followed by treatment with Geneclean.

Cloning. PCR-amplified 16S rDNA fragments were cloned by standard methods. Unique SalI and BamHI sites in the primer sequences were restricted, ligated into similarly restricted pKS II vector DNA (Stratagene, La Jolla, Calif.), and transformed into Escherichia coli DH5 $\alpha$ [supE44 $\Delta l a c U 169(\phi 80$ lacZDM15) hsdR17 recAl endA1 gyrA96 thi-1 relA1]. Plasmids were prepared by using the alkaline lysis method of Birnboim and Doly (2). The SalI-EcoRI, Eco RI-BamHI, SalI-KpnI, KpnI-PstI, and PstI-BamHI fragments of cloned 16S rDNAs were then subcloned into the same vector for sequence determinations.

Sequencing. For sequencing, plasmids were purified by using Qiagen columns (Qiagen, Inc., Chatsworth, Calif.). The DNA sequence was determined by using standard dideoxy sequencing techniques or by automated cycle sequencing. All inserts were sequenced in both directions at least three times by using the universal and reverse primers. Some regions were sequenced manually by using T7 polymerase (Sequenase; United State Biochemical Corp., Cleveland, Ohio) and primers $\mathrm{T} 3$ and $\mathrm{T} 7$. Overlapping sequences were aligned by using the
DNASIS software program (Hitachi Software Engineering America, Ltd., San Diego, Calif.).

Determination of the DNA base composition. The $\mathrm{G}+\mathrm{C}$ contents of acholeplasma DNAs were determined by the thermal melting method of Marmur and Doty (14). The DNA melting profiles in $0.1 \times$ SSC $(1 \times \mathrm{SSC}$ is $150 \mathrm{mM} \mathrm{NaCl}$ plus $15 \mathrm{mM}$ sodium citrate) were determined by using an automatic recording spectrophotometer equipped with a heated cuvette holder. The temperature was increased from 55 to $85^{\circ} \mathrm{C}$ at a rate of $1.0^{\circ} \mathrm{C} / \mathrm{min}$.

Phylogenetic analysis. Previously published 16S rRNA sequences were obtained from the GenBank database and were aligned with the sequences determined in this study for ISM1499, A. oculi $19 \mathrm{~L}$, and $A$. laidlawii PG8 by using the Pileup program of the Genetics Computer Group (6) software system, version 7.3. The aligned sequences were analyzed by using the phylogenetic analysis using parsimony package (PAUP version 3.1 [19]). A preliminary analysis was performed to verify the utility of the parsimony method for phylogenetic analysis of $16 \mathrm{~S}$ rRNA sequence data for mycoplasmas by comparison with previous phylogenetic reconstructions. Twelve of the sequences analyzed in a phylogenetic study based on 16S rRNA sequences (26) (the sequences of the 11 most terminal species in Fig. 1 of Weisburg et al. [26] plus Lactobacillus casei as an outgroup) were obtained and analyzed. Ten replicate analyses were performed by using different randomly determined input orders and global (tree bisection and reconnection) branch swapping. All nucleotide positions were analyzed without the restriction of enriching for less rapidly changing positions (26). A single shortest tree of 2,000 steps was produced (data not shown); this tree had a topology identical to the topology of the tree of Weisburg et al. (26), except that Clostridium ramosum and Clostridium innocuum diverged successively instead of as sibling species. Consequently, this method was used for further analysis.

Sequences were obtained for 14 species, and these sequences were analyzed by the branch and bound method. Two methods were used to assess the degree of support of the sequence data for the resulting tree. The first method was a bootstrap analysis in which we used 1,000 subsamples of the data matrix and regional (subpruning and regrafting) branch swapping. The second method involved examination of topological decay in all trees that were up to 10 steps longer than the shortest tree (3).

Nucleotide sequence accession numbers. The GenBank accession numbers for A. oculi 19L, A. laidlawii PG8, and strain ISM1499 16S rRNA sequences are U14904, U14905, and U14906, respectively. The GenBank accession number for A. laidlawii JA1 rRNA is M23932. Other GenBank accession numbers are shown in Table 1.

\section{RESULTS}

PCR amplification of 16S rDNA. To determine the optimum PCR conditions for acholeplasma DNAs, reactions were performed at different annealing temperatures $\left(42,45\right.$, and $\left.50^{\circ} \mathrm{C}\right)$ and with different magnesium concentrations (1 to $8 \mathrm{mM}$ $\mathrm{MgCl}_{2}$ ). The optimal magnesium concentration for ISM1499 was $1 \mathrm{mM}$, and for $A$. oculi $19 \mathrm{~L}$ and $A$. laidlawii PG8 the optimal magnesium concentration was $2 \mathrm{mM}$ (data not shown). There was no specific signal in the PCR when the annealing temperature was higher than $42^{\circ} \mathrm{C}$ (data not shown). Additional products of different lengths and having different intensities were produced. Our attempts to eliminate these products by changing the annealing temperature, the time of extension, and the concentration of the template were unsuccessful.

$16 S$ rDNA sequencing. To simplify sequencing, PCR-amplified 16S rDNAs of acholeplasma strain ISM1499, $A$. oculi 19L, and $A$. laidlawii PG8 were cloned into pKS II, and overlapping fragments were subcloned. There was no difference in the restriction patterns of the $16 \mathrm{~S}$ rDNAs (data not shown). A comparison of $A$. laidlawii JA1 and PG8 sequences obtained during this study revealed a level of homology of $98.5 \%$. The total lengths of the cloned fragments were 1,490 bp for ISM1499 and $A$. oculi $19 \mathrm{~L}$ and 1,476 bp for $A$. laidlawii PG8.

Sequence alignment and homology searches. A sequence alignment of the rDNA sequences is shown in Fig. 1. We observed two variable regions (bases 165 to 290 and 1140 to 1274) in $A$. oculi $19 \mathrm{~L}$ and ISM1499; these regions exhibited levels of homology of 88 and $80.3 \%$, respectively. When the same regions of ISM1499 were compared with the sequences of other Acholeplasma and Mycoplasma species, similar heterogeneity was observed. $A$. oculi 19L and $A$. laidlawii PG8 exhibited 95.3 and $93.4 \%$ homology with ISM1499 rDNA 


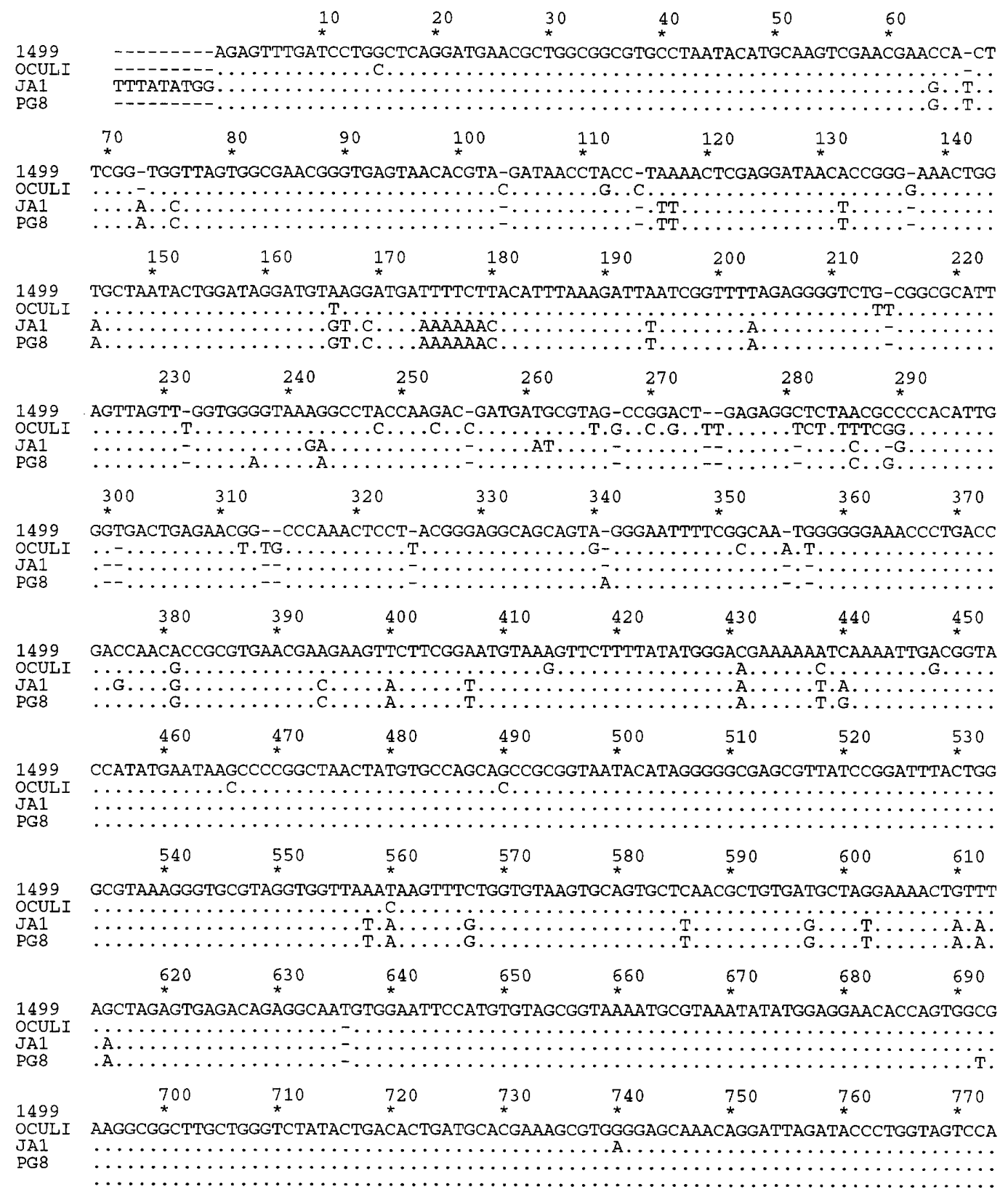

FIG. 1. Comparison of ISM1499 (1499), A. oculi ATCC 27350 (OCULI), A. laidlawii JA1, and A. laidlawii PG8 (= ATCC 23206) 16S rDNA sequences. 16S rDNA sequences were obtained either from GenBank (A. laidlawii JA1) or by performing a DNA sequence analysis as described in the text and were aligned with the sequence of ISM1499. Only the nucleotides different from the nucleotides in the ISM1499 sequence are indicated.

sequences, respectively. A. laidlawii JA1 and PG8 were $98.5 \%$ homologous (Table 2).

DNA base composition. The melting profiles of ISM1499, $A$. oculi 19L, A. laidlawii PG8, and E. coli DNAs yielded thermal denaturation values of $65.5,65.5,66.5$, and $75.5^{\circ} \mathrm{C}$, respectively. These values corresponded to $\mathrm{G}+\mathrm{C}$ contents of 28.3 mol\% for the two $A$. oculi strains, 30.7 mol\% for $A$. laidlawii PG8, and $52.7 \mathrm{~mol} \%$ for $E$. coli.

Phylogenetic analysis. A single, shortest tree consisting of 1,725 steps (retention index, 0.714) was produced by the phylogenetic analysis (Fig. 2). We found that the strain identified as ISM1499 exhibited a well-supported sibling relationship with $A$. oculi 19L (bootstrap value, 100\%; decay index value, 15).

\section{DISCUSSION}

In the past, classification of the mollicutes has been based largely on oxygen sensitivity and nutritional requirements for sterols. Acholeplasmas are non-sterol-requiring facultative anaerobes, but it is well known that these criteria are poor indicators of phylogenetic relationships. In order to get a more accurate assessment of phylogenetic positions, it is essential that phenotypic groups be confirmed by genetic analyses. DNA-DNA hybridization values and $\mathrm{G}+\mathrm{C}$ contents have been used to define species, but with acholeplasmas problems occur with the use of this classification technique. In previous studies workers have shown that levels of DNA reassociation among acholeplasma isolates range from 50 to $100 \%$ for strains 


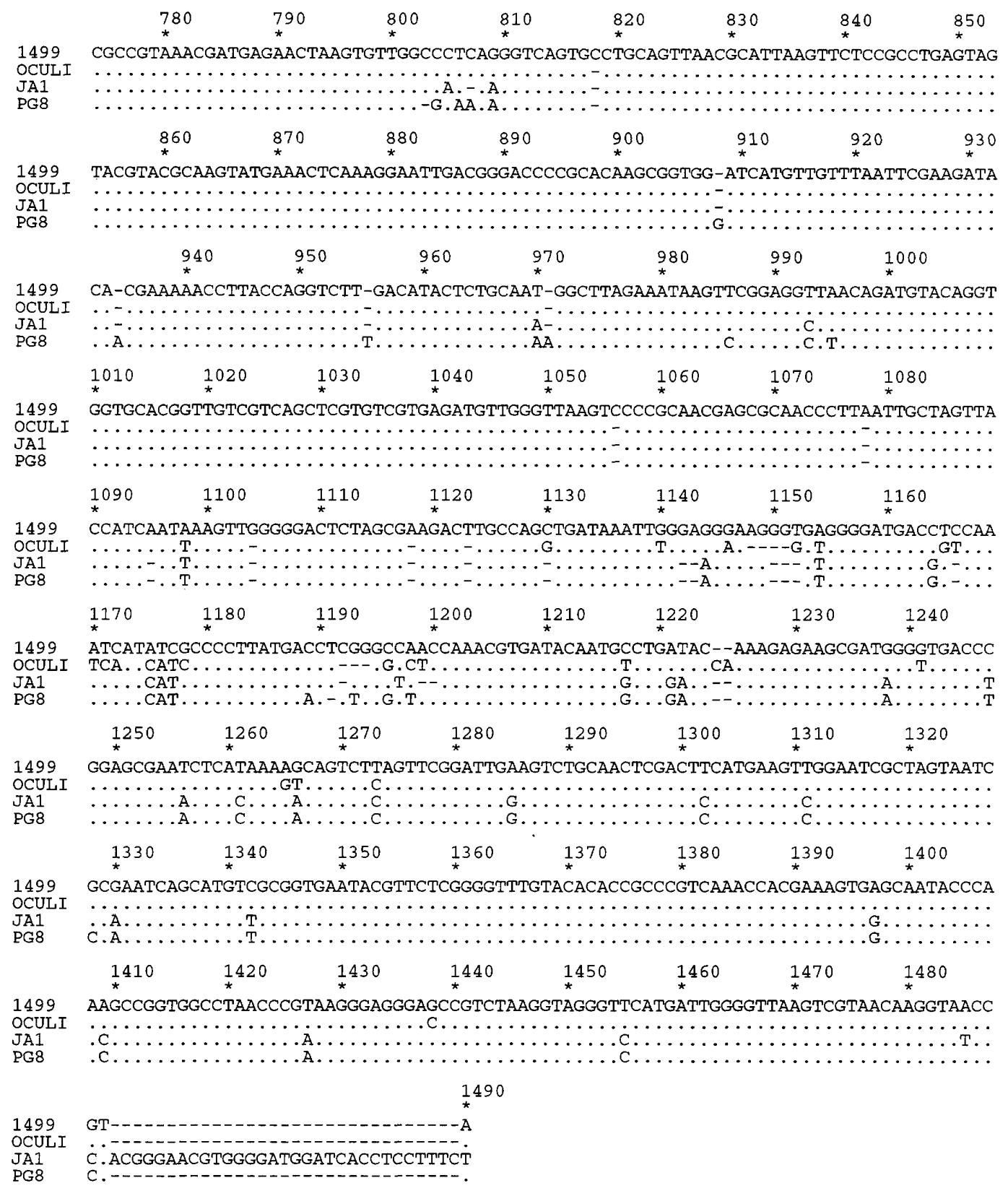

FIG. 1-Continued.

belonging to the same species and from 2 to $14 \%$ for strains belonging to different species $(1,18)$. Thus, DNA homology values could be used to distinguish between mycoplasma species, but within the genus Acholeplasma this type of differentiation is less useful. A wider species concept should be used in order to account for the great differences in homology observed between Acholeplasma species. On the other hand, it has been shown by Weisburg and his coworkers that comparative rRNA sequence analysis can be used to reconstruct mollicute phylogeny (26). Therefore, the primary sequences of the 16S rRNA genes of $A$. oculi 19L, $A$. laidlawii PG8, and ISM1499 were obtained and aligned with the $A$. laidlawii JA1 sequence (Fig. 1), and the phylogenetic relationship was determined (Fig. 2).

The data presented above conclusively demonstrate that strain ISM1499 is not a $M$. pulmonis strain as originally reported (9-12). The rRNA sequence data strongly support the hypothesis that strain ISM1499 and $A$. oculi $19 \mathrm{~L}$ are more closely related to each other than to the other species analyzed (Fig. 2). In addition, the $\mathrm{G}+\mathrm{C}$ contents of ISM1499 and $A$. oculi $19 \mathrm{~L}$ are identical $(28.3 \mathrm{~mol} \%)$. The chromosomal map of ISM1499 has been described previously (20) and is much larger than the chromosome size reported for $M$. pulmonis (16) (1,633 and $950 \mathrm{~kb}$, respectively). The pulsed-field gel electrophoresis patterns of the SmaI-digested chromosomal DNAs of ISM1499 and $A$. oculi $19 \mathrm{~L}$ were also indistinguishable $(20,22)$.

The results of a phylogenetic analysis of our $16 \mathrm{~S}$ rRNA sequence data and previously published data for other Acholeplasma species and strains confirmed that the group is monophyletic (Fig. 2) $(1,18)$. The $16 \mathrm{~S}$ rRNA sequences of $A$. 
TABLE 2. Levels of 16S rDNA homology between Acholeplasma strains

\begin{tabular}{lcc}
\hline \multirow{2}{*}{$\begin{array}{c}\text { Source of rDNA } \\
\text { sequence }\end{array}$} & \multicolumn{2}{c}{$\%$ Homology to: } \\
\cline { 2 - 3 } & $\begin{array}{c}\text { ISM1499 rDNA } \\
\text { sequence }\end{array}$ & $\begin{array}{c}\text { PG8 rDNA } \\
\text { sequence }\end{array}$ \\
\hline ISM1499 & 95.3 & 94.25 \\
A. oculi 19L & 93.4 & 93.2 \\
A. laidlawii JA1 & 93.3 & 98.5 \\
A. laidlawii PG8 & \\
\hline
\end{tabular}

laidlawii JA1 and PG8 were $98.5 \%$ homologous, but the levels of homology with $A$. oculi ISM1499 and $A$. oculi $19 \mathrm{~L}$ were only 94 and $93 \%$, respectively. There was a striking difference between the ISM1499 and $A$. oculi 19L rDNA sequences, however. A level of homology of only $95.3 \%$ between the conserved rRNA sequences of these organisms suggests that ISM1499 is a member of a subspecies of $A$. oculi or a new Acholeplasma species. More extensive examination of additional $A$. oculi strains is needed to clarify the relationship.

Even though strain ISM1499 has now been conclusively identified as a member of the genus Acholeplasma rather than a member of the genus Mycoplasma, the genetic systems developed through the use of this organism should not be

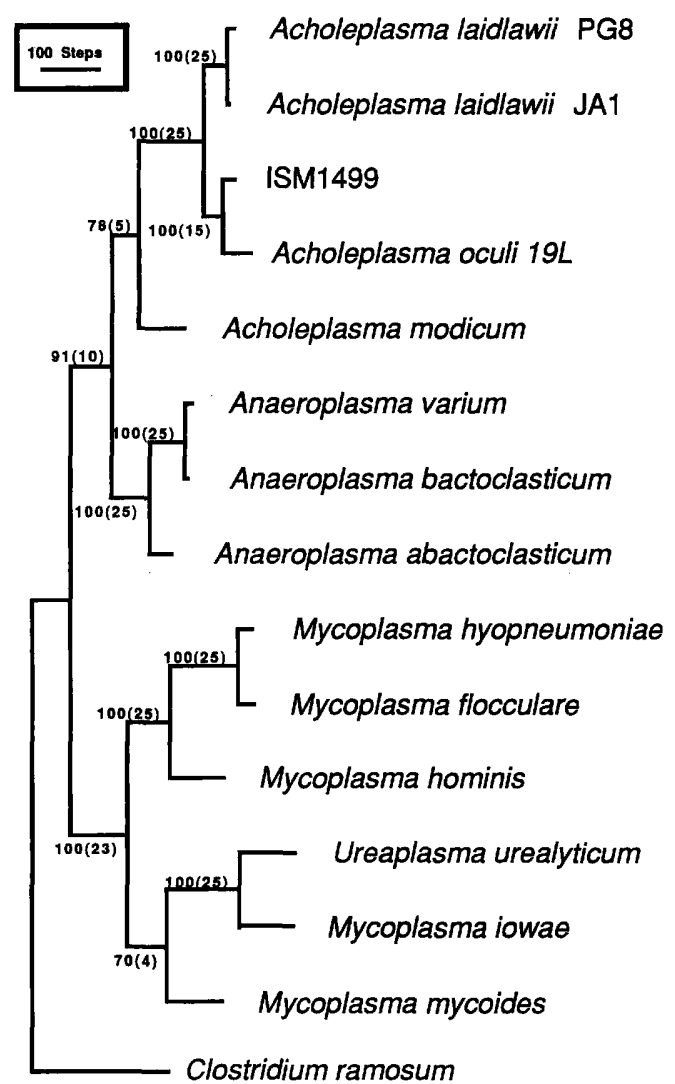

FIG. 2. Single, shortest tree for selected Acholeplasma, Anaeroplasma, Mycoplasma, and Ureaplasma species. The tree was produced by performing a phylogenetic analysis of small-subunit rRNA sequence data with PAUP software. The horizontal branch lengths are proportional to the number of steps along a branch; the scale bar represents 100 steps. The numbers along the branches indicate the strength of support of the data for each branch. The numbers preceding parentheses are percentages determined from a bootstrap analysis. The numbers in parentheses are decay values. discounted. Initially, there was concern about the use of integrative vectors and Tn4001 as genetic tools in the genus Mycoplasma because of differences in codon usage. The stop codon UGA is read as a tryptophan-coding codon in the genera Mycoplasma and Spiroplasma, but not in the genus Acholeplasma (15). The usefulness of Tn4001 and the usefulness of integrative vectors have already been established in the genus Mycoplasma $(7,8,21)$. Since there are few functioning genetic transfer systems available to mycoplasmologists, there is a continual effort to improve the versatility and usefulness of cloning systems in acholeplasmas, spiroplasmas, and mycoplasmas. As the barriers to transformation of many mollicute species fall, the genetic tools developed with ISM1499 should be used more and become more versatile.

\section{ACKNOWLEDGMENTS}

This work was supported by Cooperative State Research Service grant 91-37204-6488 from the U.S. Department of Agriculture. F.C.M. is also the recipient of U.S. Public Health Service Research Career Development Award 1K04 AI-01021 from the National Institute of Allergy and Infectious Diseases.

\section{REFERENCES}

1. Aulakh, G. S., E. B. Stephens, D. L. Rose, J. G. Tully, and M. F. Barile. 1983. Nucleic acid relationships among Acholeplasma species. J. Bacteriol. 153: 1338-1341.

2. Birnboim, H. C., and J. Doly. 1979. A rapid alkaline extraction procedure for screening recombinant plasmid DNA. Nucleic Acids Res. 7:1513-1523.

3. Bremer, K. 1988. The limits of amino acid sequence data in angiosperm phylogenetic reconstruction. Evolution 42:795-803.

4. Dybvig, K., J. Alderete, H. L. Watson, and G. H. Cassell. 1988. Adsorption of mycoplasma virus P1 to host cells. J. Bacteriol. 170:4373-4375.

5. Dybvig, K., S. K. Hollingshead, D. G. Heath, D. B. Clewell, F. Sun, and A. Woodard. 1992. Degenerate oligonucleotide primers for enzymatic amplification of rec $A$ sequences from gram-positive bacteria and mycoplasmas. J. Bacteriol. 174:2729-2732.

6. Genetics Computer Group. 1991. Program manual for the GCG package, version 7. Genetics Computer Group, Madison, Wis.

7. Heydreyda, C. T., K. K. Lee, and D. C. Krause. 1993. Transformation of Mycoplasma pneumoniae with Tn4001 by electroporation. Plasmid 30:170175.

8. Kapke, P. A., and F. C. Minion. 1994. Transformation of mycoplasmas using single-stranded DNA. Plasmid 32:85-88.

9. Mahairas, G. G., C. Jian, and F. C. Minion. 1990. Development of a cloning system for Mycoplasma pulmonis. Gene 93:61-65.

10. Mahairas, G. G., C. Jian, and F. C. Minion. 1990. Genetic exchange of transposon and integrative plasmid markers in Mycoplasma pulmonis. J. Bacteriol. 172:2267-2272. (Author's correction, 175:3692, 1993.)

11. Mahairas, G. G., and F. C. Minion. 1989. Random insertion of the gentamicin resistance transposon Tn4001 in Mycoplasma pulmonis. Plasmid 21:43-47. (Author's correction, 30:177-178, 1993.)

12. Mahairas, G. G., and F. C. Minion. 1989. Transformation of Mycoplasma pulmonis: demonstration of homologous recombination, introduction of cloned genes, and the preliminary description of an integrating shuttle system. J. Bacteriol. 171:1775-1780. (Author's correction 175:3692, 1993.)

13. Maniatis, T., E. F. Fritsch, and J. Sambrook. 1982. Molecular cloning: a laboratory manual. Cold Spring Harbor Laboratory, Cold Spring Harbor, N.Y.

14. Marmur, J., and P. Doty. 1962. Determination of the base composition of deoxyribonucleic acid from its thermal denaturation temperature. J. Mol. Biol. 5:109-118.

15. Muto, A., Y. Andachi, F. Yamao, R. Tanaka, and S. Osawa. 1992. Transcription and translation, p. 331-347. In J. Maniloff, R. N. McElhaney, L. R. Finch, and J. B. Baseman (ed.), Mycoplasmas: molecular biology and pathogenesis. American Society for Microbiology, Washington, D.C.

16. Neimark, H. C., and C. S. Lange. 1990. Pulse-field electrophoresis indicates full-length mycoplasma chromosomes range widely in size. Nucleic Acids Res. 18:5443-5448.

17. Razin, S. 1992. Mycoplasma taxonomy and ecology, p. 3-22. In J. Maniloff, R. N. McElhaney, L. R. Finch, and J. B. Baseman (ed.), Mycoplasmas: molecular biology and pathogenesis. American Society for Microbiology, Washington, D.C.

18. Stephens, E. B., G. S. Aulakh, J. G. Tully, and M. F. Barile. 1983. Intraspecies genetic relatedness among strains of Acholeplasma laidlawii and of Acholeplasma axanthum by nucleic acid hybridization. J. Gen. Microbiol. 129:1929-1934. 
19. Swofford, D. 1993. PAUP: phylogenetic analysis using parsimony, version 3.1. Illinois Natural History Survey, Champaign.

20. Tigges, E., and F. C. Minion. 1994. Physical map of the genome of Acholeplasma oculi ISM1499 and construction of a Tn4001 derivative for macrorestriction chromosomal mapping. J. Bacteriol. 176:1180-1183.

21. Tigges, E., and F. C. Minion. 1994. Physical map of the Mycoplasma gallisepticum chromosome. J. Bacteriol. 176:4157-4159.

22. Tigges, E., and F. C. Minion. Unpublished data.

23. Tully, J. G. 1979. Special features of the acholeplasmas, p. 431-449. In M. F. Barile and S. Razin (ed.), The mycoplasmas. Academic Press, New York.

24. Tully, J. G., J. M. Bove, F. Laigret, and R. F. Whitcomb. 1993. Revised taxonomy of the class Mollicutes: proposed elevation of a monophyletic cluster of arthropod-associated mollicutes to ordinal rank (Entomoplasmatales ord. nov.), with provision for familial rank to separate species with nonhelical morphology (Entomoplasmataceae fam. nov.) from helical species (Spiroplasmataceae), and emended descriptions of the order Mycoplasmatales, family Mycoplasmataceae. Int. J. Syst. Bacteriol. 43:378-385.

25. Weisburg, W. G., S. M. Barns, D. A. Pelletier, and D. J. Lane. 1991. 16S ribosomal DNA amplification for phylogenetic study. J. Bacteriol. 173:697703.

26. Weisburg, W. G., J. G. Tully, D. L. Rose, D. L. Petzel, H. Oyaizu, D. Yang, L. Mandelco, J. Sechrest, T. G. Lawrence, J. V. Etten, J. Maniloff, and C. R. Woese. 1989. A phylogenetic analysis of the mycoplasmas: basis for their classification. J. Bacteriol. 171:6455-6467. 